\title{
Cytotoxic and Apoptotic Activity on Mcf7 Cell from Ethanolic Extract of Trigonella foenum-graecum L., Aglaia elliptica Blume. and Foeniculum vulgare Mill.
}

\author{
Kurnia Agustini", Churiyah, Agung Eru Wibowo \\ Center for Pharmaceuticals and Medical Technology, \\ Laboratory for Development of Industrial Agro and Biomedical Technology, \\ Agency for the Assessment and Application of Technology (BPPT), \\ PUSPIPTEK Region, Serpong - Indonesia
}

\begin{abstract}
Indonesian medicinal herbs have so many biological activity, including anticancer activity. This assay aims to evaluate three Indonesian medicinal plants (Trigonella foenumgraecum L. (TFG), Aglaia elliptica Blume. (AE) and Foeniculum vulgare Mill. (FV) which have potency in anticancer activity. The experiment was done by MTT assay to observe the cytotoxicity activity on breast cancer cell lines MCF7. Apoptotic potency was evaluated based on \% population of MCF7 cell in subG0/GI phase. The results showed that IC 50 from ethanolic extract of TFG was 24I.24 ppm, ethanolic extract of AE was $19.442 \mathrm{ppm}$ and ethanolic extract of FV was 69.4I Ppm. Apoptotic potency for TFG was $6.46 \%$, AE was $11.94 \%$ and for FV was $8.73 \%$. Thus, it is concluded that ethanolic extract of AE gives the lowest $I_{50}$ and the higher potency of apoptotic by significantly $(p<0.05)$ increase \% population of cells in subG0/GI phase on 100ppm concentration.
\end{abstract}

Keywords : Trigonella foenum-graecum L., Aglaia elliptica Blume. and Foeniculum vulgare Mill., MCF-7, Apoptotic, Cytotoxic

\section{INTRODUCTION}

Cancer is the second leading cause of death worldwide. Many research to find anticancer drug and new treatment for handling it already have been made a great advancement, though a number of undesired side effects still occur during chemotherapy. So that's why research about natural product or natural therapies still carry on to reduce many side effect during treatment or to find new compound candidate for more safety anticancer drug. Indonesia with great properties of medicinal plants also have a big potency to for new anticancer drug discovery research.

Many preliminary study were carried out in our laboratory (BPPT), including screening extracts from many medicinal plants suspected as anticancer. We started with in vitro assay using various cancer cell lines to observe the cytotoxicity effect. In this paper, we explore about the potency of cytotoxic and apoptotic activity of Indonesian medicinal plants such as Trigonella foenum-graecum L (TFG), Aglaia elliptica Blume. (AE) and Foeniculum vulgare Mill. $(F V)$.
Fenugreek seed or Foenigraeci semen is dried seed from Trigonella foenum-graecum L., (TFG), Leguminosae, (WHO, 2007). In bahasa, it is called biji Klabet. Empirically, TFG seed was used for hemorrhoids, asthma, ulcers, muscle pain and often used as a preventative hair loss and skin softener. Many studies showed its activity as antidiabetic, anticancer and for hypercholesterolemia handling. From previous study (Agustini, et al., 2007) showed that ethanolic extract of TFG seed revealed to have estrogenic effect on ovariectomized and immature female Wistar rats. Phytoestrogen also have potency to handle depending on hormonal breast cancer which is known as natural Selective Estrogen Receptor Modulators (SERMs).

*Corresponding author e-mail: kurnia.agustini@gmail.com 

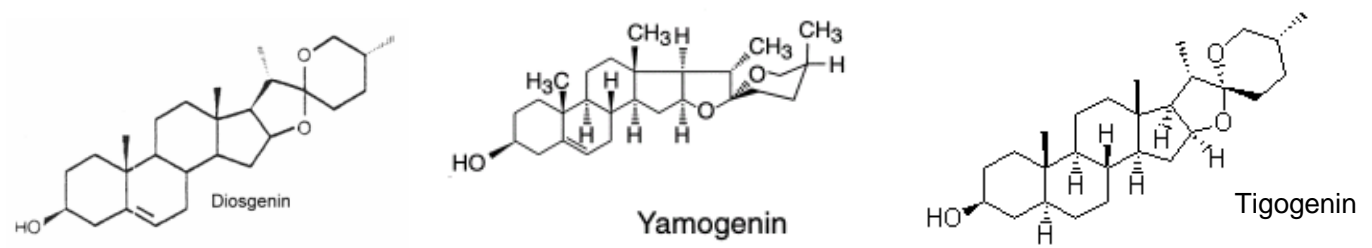

Figure I. Some Sapogenin Steroids of Trigonella foenum-graecum L.

TFG contains sapogenin steroids (diosgenin, yamogenin, gitogenin, gitogenin, trigoneosida, protodioscin), alkaloid trigonelline and flavonoids, e.g., vitexin, isovitexin, orientin, vicenin, quercetin and luteolin (Hoffman, 2004), essential oil, saponine, nicotinamide, choline, bitter compound and mucilage (Evans, 2002).

Aglaia elliptica Blume is one of Indonesian medicinal plant from Meliaceae family that traditionally used as wound healing, antiheadeache, antiasthma, antiinflamation and tonic. Some pharmacological research investigated the activity of $\mathrm{AE}$ as insecticide, anticancer antibacterial, antivirus, anthelmintic and antifungal. AE contain active compound such as rocaglamide, aglain, odorin, odorinol, forbaglines, thapoxepines (Wibowo, 2011).

Foeniculum vulgare Mill or Fennel fruit is a widespread perennial umbeliferous (Apiaceae) herb, traditionally used for human consumption and medicinal purposes, especially recommended for diabetes, bronchitis and chronic coughs, and for the treatment of kidney stones (Barros, et al., 2009). GC-MS analysis of the fennel essential oils revealed the presence of trans-anethole, fenchone, estragole and limonene as the main components in the mature fruit. Both the essential oils and trans-anethole were principal constituent which exhibited appreciable antioxidant and antimicrobial activities (Anwar, et al., 2009). These essential oils also had high antibacterial activity against food-borne pathogenic bacteria Staphylococus aureus (Soylu, et al., 2009). For millennia, Fennel has been used as estrogenic agents, such as increase milk secretion, promote menstruation, facilitate birth, alleviates the symptoms of the male climacteric and increase libido. The main constituent of the essential oils of fennel has been considered to be the an active estrogenic agent (Puleo, 1979). Therefore, this study was conducted to observe the cytotoxic and apoptotic activity of ethanolic extracts of TFG, $\mathrm{AE}$ and $\mathrm{FV}$ using in vitro methods such as MTT assay and flowcytometry.

\section{MATERIALS AND METHODS}

\section{Sample Preparation}

TFG seeds and FV fruits were obtained from Tawangmangu, Central Java, while AE leaves were obtained from Kebun Raya Bogor. Simplicia were dried and grind, then extracted with ethanol $96 \%$ food grade. Each extract were dried with vacuum rotary evaporator.

\section{Cell Culture}

MCF7 cell culture were obtained from Laboratory for Development of Industrial Agro and Biomedical Technology (LAPTIAB-BPPT) Indonesia. Cells were routinely maintained and grown in $75 \mathrm{~cm}^{2}$ flasks at $37^{\circ} \mathrm{C}, 5 \% \mathrm{CO}_{2}$ and in a 95\% humidified atmosphere. The growth medium was prepared as following: RPMI 1640 (Gibco) with phenol red and $2 \mathrm{mM}$ glutamine, $100 \mathrm{U} / \mathrm{mL}$ penicillin, $0.1 \mathrm{mg} / \mathrm{mL}$ Streptomycin, $1 \mathrm{mM}$ sodium pyruvate and supplemented with $10 \%$ Fetal Bovine Serum (FBS) (Gibco) which already heat inactivated at $56^{\circ} \mathrm{C}$ for $30 \mathrm{~min}$. Passaging of cells was carried out using $4 \mathrm{~mL}$ of trypsin-EDTA at room temperature for 75 $\mathrm{cm}^{2}$ flask, respectively for $3 \mathrm{~min}$. After that, 10 ml media with $10 \%$ FBS were used to reduce the action of trypsin on cells. After centrifugation, the obtained cells were platted.

\section{Cytotoxicity Assay with MTT Method}

Cells were platted into 96-well plates $(10,000$ cells/well) in medium RPMI with phenol red containing 10\% Fetal Bovine Serum (FBS), $100 \mathrm{U} / \mathrm{mL}$ penicillin, $0.1 \mathrm{mg} / \mathrm{mL}$ streptomycin and $1 \mathrm{mM}$ sodium pyruvate, then incubated for 24 hours at $37^{\circ} \mathrm{C}, 5 \% \mathrm{CO}_{2}$ and in a $95 \%$ humidified atmosphere. After 24 hours, medium was changed with sample in growth medium with different concentration and 
incubated for another 24 hours at $37^{\circ} \mathrm{C}, 5 \%$ $\mathrm{CO}_{2}$ and in a $95 \%$ humidified atmosphere. Assays were done in wide range concentration, from $10 \mathrm{ppm}$ until $500 \mathrm{ppm}$, divided into six variation concentration. After 24 hours of treatment, the cells were washed with Phosphate Buffer Saline (PBS). Then the MTT solution in medium, was added followed by incubation for 4 hours at $37^{\circ} \mathrm{C}, 5 \% \mathrm{CO}_{2}$ and in a $95 \%$ humidified atmosphere until the crystal of formazan will be formed. After that, reaction was stopped by added Sodium Dodecyl Sulphate (SDS) into every well. The plate than incubated in dark place (room temperature) for 12 hours (overnight). The intensity of the color formed was measured by ELISA reader at 570 nm.

\section{Apoptotic Assay with Flowcytometry}

Cells were platted into 24-well plates $(30,000$ cells/well $)$ in growth medium then incubated for 24 hours at $37^{\circ} \mathrm{C}, 5 \% \mathrm{CO}_{2}$ and in a $95 \%$ humidified atmosphere. After 24 hours, medium was changed with samples (ethanolic extract of TFG, AE and FV) with 100 ppm concentration in growth medium (triplo) and incubated for another 24 hours at $37^{\circ} \mathrm{C}, 5 \%$
$\mathrm{CO}_{2}$ and in a 95\% humidified atmosphere. The cells were harvested with trypsin in PBS for 3 minutes to detach the cells. Cell suspension were centrifuged to obtain the cell pellet. Cell was fixated with ethanol $70 \%$ for 15 minutes in $4^{\circ} \mathrm{C}$ and centrifuged again for 5 minutes. Then supernatant were resuspended with $450 \mu \mathrm{L}$ PBS. The suspension then stained with Propidium Iodida (PI) $20 \mu \mathrm{g} / \mathrm{mL}$ and incubated in the dark room at room temperature for 30 minutes. The staining cell was measured by flowcytometer (Beckman-Coulter ${ }^{\circledR,}$ EPICS-XL) to analyze the cell cycle. The result was analyzed statistically.

\section{RESULTS AND DISCUSSIONS}

The results of cytotoxicity activity with MTT assay can be seen in Fig. 2. All graphics showed that $\%$ growth of MCF7 cells lowered as increasing concentration, proved that TFG, $\mathrm{AE}$ and FV inhibited MCF7 cells proliferation in dose dependent manner. Inhibition concentration were determined to compare the concentration caused $50 \%$ of growth inhibition. The $\mathrm{IC}_{50}$ of three samples were described in Table 1.
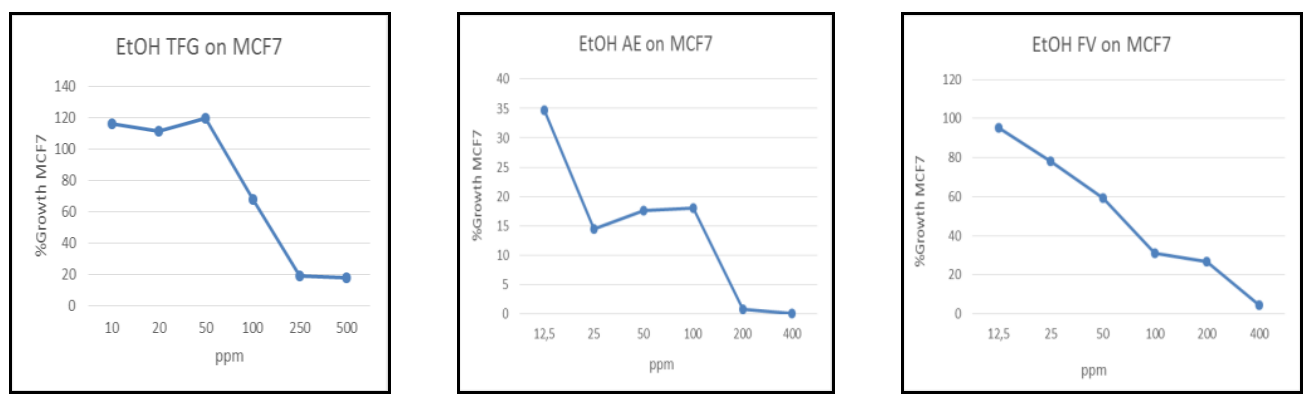

Figure 2. The cytotoxic effect of samples on MCF-7 cells. The cells were treated with samples in the concentration of 10-500 ppm and incubated for 24 h. After 24 hours, Cells were added by MTT reagent to calculate the absorbance which represent viable cells. Diagram of MCF-7 cells viability after 24 hours after treatment with TFG $(A), A E(B)$, and FV $(C)$.

Table I. IC50 of ethanolic extract of all samples

\begin{tabular}{ccc}
\hline No. & Samples & IC50 (ppm) \\
\hline I & EtOH - TFG & 241.24 \\
$\mathbf{2}$ & EtOH - AE & 19.442 \\
$\mathbf{3}$ & EtOH - FV & 69.41
\end{tabular}


The results revealed that ethanolic extract of $\mathrm{AE}$ showed the lowest value of $\mathrm{IC}_{50}$. We suggested that ethanolic extract of $\mathrm{AE}$ had cytotoxicity activity better than either TFG or FV.

Furthermore, to observe the potency of these sampels in apoptotic induction, we analyzed by using Flowcytometer. As control we use normal cell, DMSO (sample's solvent), control of chemotherapy drug doxorubicin $1 \mu \mathrm{M}$ and control of chemoprevention drug tamoxifen $10 \mu \mathrm{M}$. The amount of cells in each phase of cell cycle that were stained with Propidium Iodida (PI), and measured by flowcytometer. The result could be seen at Fig. 3, meanwhile the percentage cells in subG0/G1 phase could be seen in Table 2 .

Flowcytometer worked by analyzing all type of cells in a cell population, which already stained with fluorescent. Analysis of each phase in cell cycle, apoptotic cells and polyploidy cells can be observed in a cancer cells population treated with cytotoxic samples.

Cells in different phase have different number of chromosomes set, which are phase subG0/G1, phase $S$, phase $\mathrm{G} 2 / \mathrm{M}$ have 2,3 and 4 chromosomes set respectively. If the number of chromosomes set is higher, then the optical signal intensity given become stronger too because the ability of fluorescence to intercalate with DNA become bigger. In a apoptotic cells (sub G0/G1), the fluorescence intensity is weak because the chromosomes already fragmented, while in polyploidy cells, the intensity given are strong because they have more than four chromosome sets (Rabinovitch, 2002).

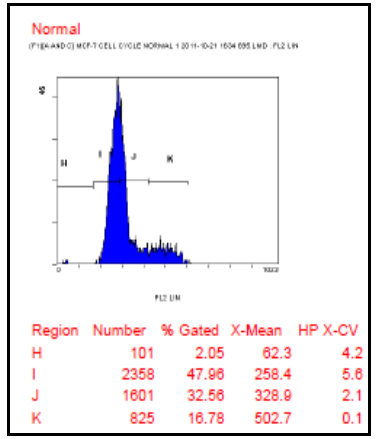

(A)

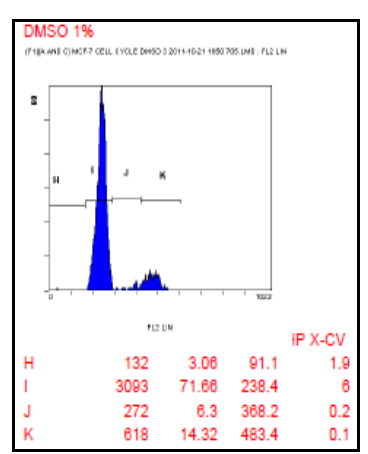

(B)

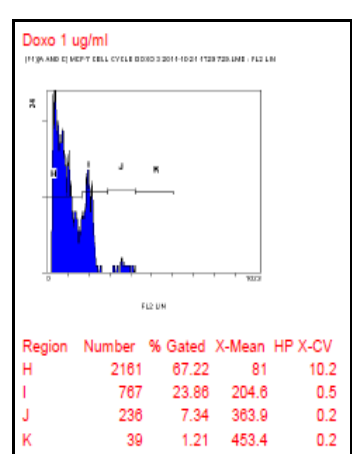

(C)

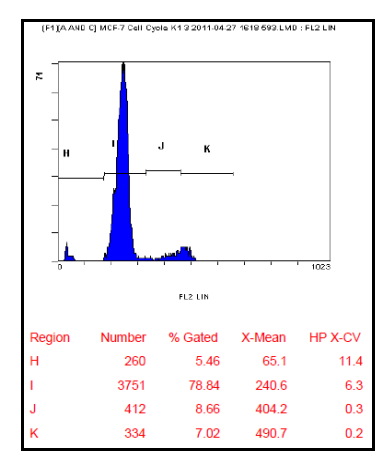

(D)

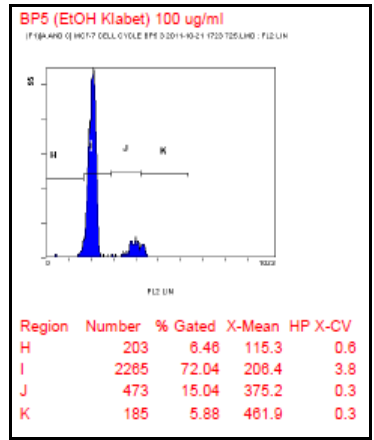

(E)

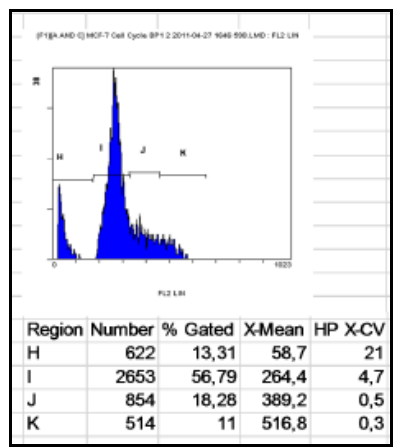

(F)

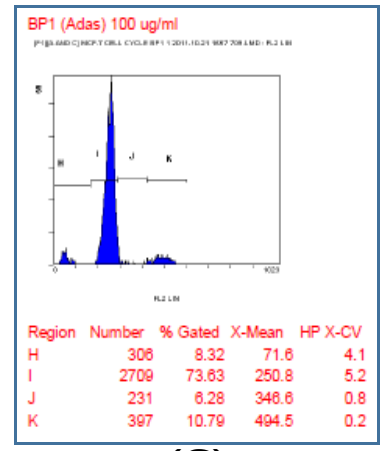

(G)

Figure 3. Flowcytometer measurement of MCF7 cells after treatment with samples for 24 hours. (A) Normal control without treatment, (B) DMSO control, (C) doxorubicin, (D) Control of chemoprevention drug, tamoxifen, (E) EtOH-TFG, (F) EtOH-AE dan (G) EtOH-FV. Region H, I, J, K show the phase in cell cycle, $\mathrm{H}=\mathrm{G} 0 / \mathrm{GI}, \mathrm{I}=\mathrm{GI}, \mathrm{J}=\mathrm{S}$ and $\mathrm{K}=\mathrm{G} 2 / \mathrm{M}$. 
Table 2. Cell Percentage sub G0/G I phase of cell cycle

\begin{tabular}{lccc}
\hline \multicolumn{1}{c}{ Samples } & \% cells in sub G0/G I & SD & T-test \\
\hline Normal & 2.64 & 0.96 & \\
DMSO & 2.97 & 0.19 & 0.5903 \\
Doxorubicin & 51.96 & 14.83 & 0.0045 \\
Tamoksifen & 5.34 & 0.10 & 0.0602 \\
EtOH - TFG & 6.46 & 0.94 & 0.0078 \\
EtOH - AE & 11.94 & 1.94 & \\
EtOH - FV & 8.73 & 0.49 & 0.001 \\
\hline
\end{tabular}

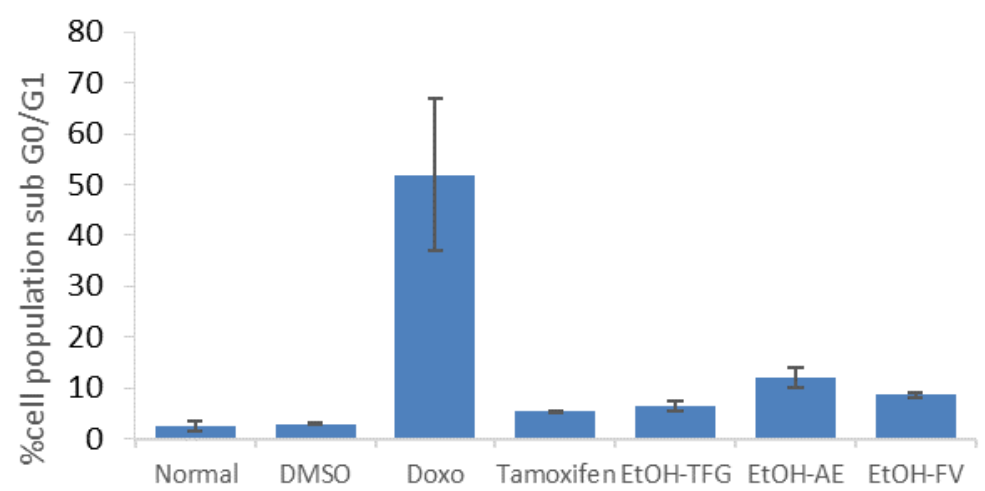

Figure 4. Comparation of the percentage cells population sub G0/GI after treatment with samples for 24 hours.

Doxorubicin and tamoxifen showed different cell cycle graphics profile based on this experiment, while ethanolic extract of TFG and FV gave similar cell cycle graphics profile with tamoxifen, AE gave similar profile with doxorubicin. Treatment with Doxorubicin $1 \mu \mathrm{M}$ gives the higher \% cells population in apoptotic phase. Cell population treated with tamoxifen, TFG and FV were higher in G1 phase. Tamoxifen is known for its activity as Selective Estrogen Modulator (SERMs) which is a drug choice to treat dependent hormonal breast cancer with positive estrogen receptor/ER(+). SERMs group have agonist partial activity on estrogen receptor that can inhibit proliferation in the beginning until in the middle of G1 phase (Gauduchon, 2003). MCF7 cells is known as one of breast cancer cell line with ER (+). Agustini, et al $(2005$; 2006) showed that ethanolic extract of TFG and FV were having activity as phytoestrogen that give estrogenic effect on immature rats and ovariectomized adult rat. It is well known that phytoestrogen are widely observed as natural SERMs.
Based on the percentage cells population sub G0/G1, ethanolic extract of TFG, AE and $\mathrm{FV}$ on $100 \mathrm{ppm}$ induced apoptotic significantly $(p<0.05)$ compared to normal control. All three samples also induced apoptotic higher than tamoxifen $10 \mu \mathrm{M}$.

\section{CONCLUSION}

We conclude that ethanolic extract of $\mathrm{AE}$ can inhibit proliferation and induce apoptotic better than TFG and FV, though three of them significantly $(p<0.05)$ increase \% population of cells in subG0/G1 phase on $100 \mathrm{ppm}$ concentration.

\section{ACKNOWLEDGEMENTS}

We thank Dr. Tjandrawati Mozef, M.Sc., Research Center for Chemistry (PuslitkimLIPI) for flowcytometry analysis. 


\section{REFERENCES}

Agustini, K., Suyatna, F., Siregar, N.C. and Sumaryono, W., 2013, Aktivitas Biji Klabet (Trigonella foenum-graecum L.) terhadap Pertumbuhan dan Apoptosis Sel Kanker Payudara MCF-7, Jurnal IImu Kefarmasian Indonesia, I I (I), I3-20.

Agustini, K. and Saepudin, Y., 2006, Pengaruh Ekstrak Buah Adas (Foeniculum vulgare Mill.) terhadap Kadar Hormon Estradiol dan FSH Plasma Tikus Putih Betina Galur Wistar yang Diovariektomi, Majalah IImiah Artocarpus, Media Pharmaceutica Indonesiana, 6(2).

Agustini, K., Wiryowidagdo, S. and Kusmana, D., 2005, Pengaruh Pemberian Biji Klabet (Trigonella foenum-graecum L.) terhadap Kadar Hormon Estradiol dan FSH Plasma Tikus Putih Betina Galur Wistar yang Diovariektomi, Proceeding, Seminar Nasional Penggalian Potensi Sembilan Tanaman Obat Unggulan Indonesia, Purwokerto.

Anwar, F., Hussain, A.I., Sherazi, S.T.H. And Bhanger, M.I., 2009, Changes in Composition and Antioxidant and Antimicrobial Activities of Essential Oil of Fennel (Foeniculum vulgare Mill.) Fruit at Different Stages of Maturity, J. Herbs. Spices Med. Plants, I 5(2), I87-202.

Barros, L., Heleno, S.A., Carvalho, A.M. and Ferreira, I.C., 2009, Systematic Evaluation of the Antioxidant Potential of Different Parts of Foeniculum vulgare Mill. from Portugal, Food Chem. Toxicol., 47(I0), 2458-2464.

Evans, C.W., 2002, Pharmacognosy, I5th Edition, London: W.B. Saunders.

Gauduchon, J., Gouilleux, F., Maillard, S., Marsaud, V., Renoir, M.J. and Sola, B, 2003, The Selective Estrogen Receptor Modulator 4-hydroxy tamoxifen Induces
GI Arrest and Apoptosis Multiple Myeloma Cell Lines, Ann. N.Y. Acad. Sci., I 010, 321-325.

Hoffman, J. and Sommer, A., 2007, AntiHormone Therapy: Principles of Endocrine Therapy of Cancer, In: Bradbury, editor, Cancer, Topic in Medicinal Chemistry, Berlin: RH. Springer, $21-80$

Albert, P.M., 1980, Fennel and Anise as Estrogenic Agents, J. Ethnopharmacol., 2(4), 337-344.

Raju, J., Patlolla, J.M., Swamy, M.V. and Rao, C.V., 2004, Diosgenin, a Steroid Saponin of Trigonella foenum graecum (Fenugreek), Inhibits AzoxymethaneInduced Aberrant Crypt Foci Formation in F344 Rats and Induces Apoptosis in HT-29 Human Colon Cancer Cells, Cancer Epidemiol. Biomarkers Prev., I3(8), I392-I 398.

Rabinovitch, P.S., 2002, Multicycle for windows, Multicycle DNA Content and Cell Cycle Analysis Software, Washington: University of Washington. Phoenix Flow System Inc.

Soylu S, Soylu EM, Evrendilek GA. 2009. Chemical Composition and Antibacterial Activity of Essential Oils of Bitter Fennel (Foeniculum vulgare Mill. Var. Vulgare) and Dill (Anethum graveolens I.) Against the Growth of Food-Borne and Seedborne Pathogenic Bacteria, Ital. J. Food Sci., 2 I (3), 347-355.

WHO, 2007, WHO Monograph on Selected Medicinal Plants-Volume 3, Otawa: World Health Organization.

Wibowo, A.E., 20I I, Anticancer Activity of Laban Abang Leaves (Aglaia elliptica Blume): Extraction, Active Compound Identification, In Vitro and In Vivo Assay, Disertation, Medical Faculty, University of Indonesia, Jakarta. 